\title{
Spain's science policy needs a U-turn
}

\author{
Mariano Rajoy's promises to make science a priority requires sparing it from austerity.
}

In 2009, Spanish biochemist Joan Guinovart argued that Spain was wrecking its science "for the cost of six Ronaldos". The country was about to begin a rush of science budget cuts that have not stopped since. Guinovart, then president of the Confederation of Scientific Societies of Spain (COSCE), meant that the austerity that hurt science so much was a little saving for the overall state's budget: equivalent to the cost of hiring a bunch of football players.

Since then, the spending cuts have increased by several 'Ronaldos', and Spanish science is now in a critical state. The government of Mariano Rajoy (People's Party, pictured) is still on time to fulfil its promises to place research and development as a priority, but this requires a U-turn in its science policy.

After a decade of increases in science funding, Spain started to cut its research and development spending in 2010, when José Luis Rodríguez Zapatero (Socialist Party) was in charge. Since then, investment in science has reduced each year and the government has cut its total investment by $39 \%$ from the level of $2009^{1}$. The combination of austerity and recession made the percentage of gross domestic product (GDP) invested in science fall for the first time in 2011, down to $1.33 \%$. In the same year, the number of people devoted to science was $3.1 \%$ less than in 2010, a possible sign of a brain drain ${ }^{2}$.

The physical sciences have had their share of austerity. Beyond the cuts imposed on the National Council for Scientific Research (CSIC) and the universities, centres like the Canary Island Institute of Astrophysics (IAC) and the Centre for Research in Energy, Environment and Technology (CIEMAT) have seen state funding fall by $25 \%$ and $29 \%$, respectively, since 2009. The Alba synchrotron, inaugurated in 2010 with seven beam lines approved, will not have more approved until the end of 2013 at least, although it is designed to have 32. Moreover, Spain owes money to CERN and the European Science Foundation $(\mathrm{ESF})^{3}$, and has reduced its participation in the ESA's optional programmes by $75 \%$. Also, it is still unclear whether it will continue to participate in the European Extremely Large Telescope (E-ELT) project.
The situation was worsened by Rajoy's decision to absorb the science ministry into the economy ${ }^{4}$. Moreover, the biotechnologist responsible for science in the government, the secretary of state Carmen Vela, seems to be a hostage of the minister of finance, Cristóbal Montoro. His ministry has blocked the creation of a Research State Agency announced by Vela, imposed delays in calls and in their resolution, and denied the transfer of money to groups that had won past calls, with the argument that the region where they operate had not fulfilled deficit limits imposed by the state.

The bewilderment produced by these policies triggered in 2012 the Carta abierta por la ciencia movement ${ }^{5}$, an unprecedented joint effort by all scientific actors (from societies to unions) to protest against cuts. This has given a public voice to a scientific community traditionally passive in policy debates. But the protests are far from the intensity of others, like the ones of France's Sauvons la Recherche in 2004, when a thousand group leaders signed a common resignation letter in protest to cuts ${ }^{6}$.

Spain still owns a large capital of science and innovation. It is ranked ninth in the world in terms of the number of publications, and hosts excellent research groups (like those funded by the Consolider programme, which has now closed) and research centres (like those awarded by the Severo Ochoa programme ${ }^{7}$ ).

Carmen Vela wrote in Nature ${ }^{8}$ that budget cuts should be turned into an opportunity to prioritize excellence. Most scientific organizations agree that reforms are necessary to better reward merit, but they feel that talking about excellence is an excuse to divert attention from the alarming lack of funds: excellence needs a strong scientific system as a base. The science strategy set up by the government plans to reach a target of investing $2 \%$ of the GDP in science by 2020. But it aims to do so without more public funding: only by stimulating an increase in private funding. It is unlikely that this will work, given the current financial conditions of the private sector 9 .

If Rajoy really wants to make science a priority, he should urgently coordinate the actions of the economy and the finance ministries, to spare research and

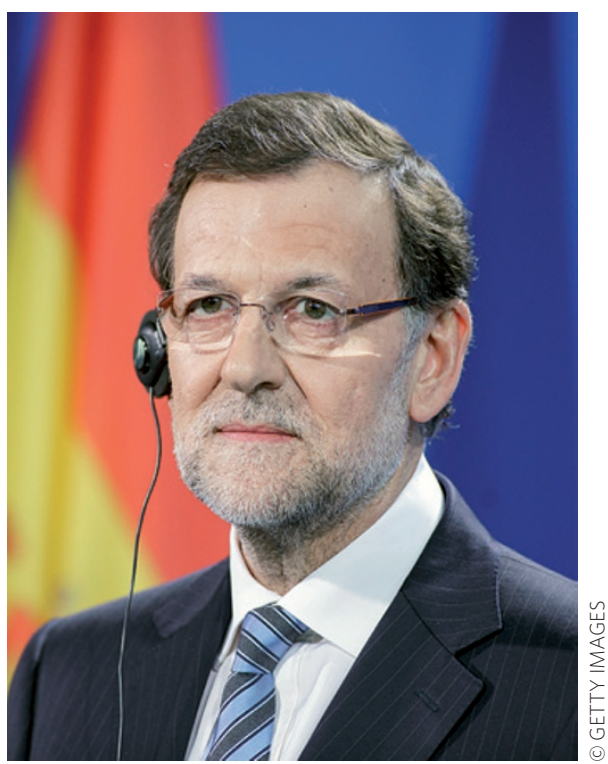

development from draconian austerity measures. International commitments should be respected, calls should be resolved on time, assigned funds should be delivered in a timely fashion, and the permission to hire new scientists in the public sector should be used (at present only one engagement for every ten retirements has been allowed, but several centres are not able to accomplish even such a low rate).

Both the majority and the opposition agree that science and innovation are the keys to overcoming the current recession, so further cuts in next year's budget would be incomprehensible. Otherwise, the government's commitment to science will continue to be non-existent, and Spain will end up eating all its seed corn.

\footnotetext{
References

1. http://blogs.nature.com/news/2012/12/spanish-scientists-take-tothe-streets.html

2. http://www.nature.com/naturejobs/science/articles/ $10.1038 \% 2$ Fnj7425-629a

3. http://news.sciencemag.org/scienceinsider/2013/03/unpaid-duesdelay-spanish-partic.html

4. http://www.nature.com/news/spain-cuts-science-ministry-ingovernment-changeover-1.9725

5. http://blogs.nature.com/news/2012/12/spanish-scientists-take-tothe-streets.html

6.tt://www.timeshighereducation.co.uk/187378.article

7. http://blogs.nature.com/news/2011/10/spains_top_research centres_ge.html

8. http://www.nature.com/news/turn-spain-s-budget-crisis-into-anopportunity-1.10770

9. http://news.sciencemag.org/scienceinsider/2013/02/lofty-goalsin-spanish-research-.html
} 